\title{
Thermonema rossianum sp. nov., a New Thermophilic and Slightly Halophilic Species from Saline Hot Springs in Naples, Italy
}

\author{
SANDRA TENREIRO,${ }^{1}$ M. FERNANDA NOBRE, ${ }^{2}$ FRED A. RAINEY, ${ }^{3}$ CARLA MIGUEL,${ }^{1}$ \\ AND MILTON S. DA COSTA ${ }^{1 *}$ \\ Departamento de Bioquímica ${ }^{1}$ and Departamento de Zoologia, ${ }^{2}$ Universidade de Coimbra, 3000 Coimbra, Portugal, \\ and Deutsche Sammlung von Mikroorganismen und Zellkulturen, 38124 Braunschweig, Germany ${ }^{3}$
}

\begin{abstract}
Six slightly halophilic, thermophilic bacterial strains were isolated from saline hot springs along the Bay of Naples, Italy. These strains produce bright yellow colonies and have a filamentous morphology and an optimum growth temperature of about $60^{\circ} \mathrm{C}$. Lipid composition and $16 \mathrm{~S}$ ribosomal DNA sequence analyses showed that these strains belong to the genus Thermonema, a member of the cytophaga-flavobacter-bacteroides phylum. Growth was observed in medium containing 1 to $3 \% \mathrm{NaCl}$. The DNA G+C content was 50.9 mol\%. DNA-DNA hybridization studies showed that these strains represent a new species of the genus Thermonema. We propose that strain $\mathrm{NR}-27^{\mathrm{T}}(\mathrm{T}=$ type strain) and the other strains represent a new species, Thermonema rossianum. Strain NR-27 (= DSM 10300) is the type strain of this species.
\end{abstract}

The majority of the thermophilic members of the Bacteria have been isolated from continental geothermal areas throughout the world where the sodium concentration is low, but thermophilic and hyperthermophilic aerobic species, such as Thermus thermophilus, Rhodothermus marinus, Aquifex pyrophilus, and anaerobic species of the order Thermotogales, have also been isolated from marine hot springs where the salinity is lower than or similar to that of seawater $(1,2,15,17)$. Most of the organisms originating from marine hot springs are slightly halophilic and are, therefore, restricted to saline thermal environments. However, Thermus thermophilus is a halotolerant organism that has also been isolated from continental hot springs with low sodium contents (14).

The thermophilic bacterium Thermonema lapsum is represented by a few strains isolated from continental hot springs in New Zealand $(8,22)$. These strains are filamentous, have gliding motility, form yellow-pigmented colonies, and have an optimum growth temperature of about $60^{\circ} \mathrm{C}$ and a maximum growth temperature of about $70^{\circ} \mathrm{C}$. This species has been shown to represent a deep branch within the cytophaga-flavobacter-bacteroides phylum. This species also possesses relatively large proportions of hydroxy fatty acids and ninhydrinpositive polar lipids, as do many species belonging to this phylum (18).

We recently isolated several yellow-pigmented filamentous strains from saline hot springs near Naples, Italy, and these strains had phenotypic and chemotaxonomic characteristics that were very similar to those of Thermonema lapsum. However, unlike Thermonema lapsum, the new isolates from Naples were slightly halophilic. In this paper we describe a new species of the genus Thermonema, for which the name Thermonema rossianum is proposed.

\section{MATERIALS AND METHODS}

Isolation and bacterial strains. Strains NR-7 and NR-2 $27^{\mathrm{T}}(\mathrm{T}=$ type strain) were isolated from a thermal water tap at the Stufe di Nerone; strains SC-1, $\mathrm{SC}-3$, and SC-5 were isolated from the vent located by the beach at the Ris-

* Corresponding author. Mailing address: Departamento de Bioquímica, Apartado 3126, Universidade de Coimbra, 3000 Coimbra, Portugal. Phone: 351-39-24024. Fax: 351-39-26798. E-mail: milton @cygnus.ci.uc.pt. torante lo Scoglio; and strain AG3-1 was isolated from a hot pool at the Termi di Agnano. Water samples were transported without temperature control, and the samples were filtered within 5 days through membrane filters (Gelman type GN-6; pore size, $0.45 \mu \mathrm{m}$; diameter, $47 \mathrm{~mm}$ ); the filters were placed on the surfaces of medium 162 (4) agar plates containing $1.0 \% \mathrm{NaCl}$, which were wrapped in plastic bags and incubated at $60^{\circ} \mathrm{C}$ for up to 7 days. Cultures were purified by subculturing and were maintained at $-80^{\circ} \mathrm{C}$ in medium 162 containing $1.0 \% \mathrm{NaCl}$ and $15.0 \%$ glycerol. Thermonema lapsum DSM $5718^{\mathrm{T}}$ was obtained from the Deutsche Sammlung von Mikroorganismen und Zellkulturen, Braunschweig, Germany.

Morphological, biochemical, and tolerance characteristics. Unless otherwise stated, all morphological, biochemical, and tolerance tests were performed as described previously $(14,17,21)$ in medium 162 containing $2.5 \mathrm{~g}$ of yeast extract per liter and $2.5 \mathrm{~g}$ of tryptone per liter without added $\mathrm{NaCl}$ or supplemented with $1.0 \% \mathrm{NaCl}$ for the new isolates and incubated at $60^{\circ} \mathrm{C}$ for up to 3 days. The growth temperature ranges of Thermonema lapsum DSM $5718^{\mathrm{T}}$ and strains SC-1 and NR $-27^{\mathrm{T}}$ were examined by measuring the turbidity at $610 \mathrm{~nm}$ of cultures grown in $300-\mathrm{ml}$ metal-capped Erlenmeyer flasks containing $100 \mathrm{ml}$ of medium 162 in a reciprocal water bath shaker. The salt range for growth was examined as described above by adding different amounts of $\mathrm{NaCl}$ to the culture medium. The $\mathrm{pH}$ range for growth was examined in medium 162, as described above, by using $20 \mathrm{mM}$ MES [2-( $N$-morpholino)ethanesulfonic acid] between $\mathrm{pH} 5.0$ and 6.5 , Tris between $\mathrm{pH} 7.0$ and 8.5, and CAPSO [3-(cyclohexylamino)-2-hydroxy-1propanesulfonic acid] between $\mathrm{pH} 9.0$ and 10.5 .

Carbon source assimilation tests were performed in a minimal medium composed of medium 162 basal salts containing $1.0 \% \mathrm{NaCl}$ for the new isolates to which filter-sterilized ammonium sulfate $\left(0.5 \mathrm{~g} \mathrm{liter}^{-1}\right)$ and yeast extract $(0.3 \mathrm{~g}$ liter ${ }^{-1}$ ) were added. Growth was examined by measuring the turbidity of cultures grown in 300-ml metal-capped Erlenmeyer flasks containing $100 \mathrm{ml}$ of medium and incubated at $60^{\circ} \mathrm{C}$ for up $24 \mathrm{~h}$ as described above. Positive control cultures were grown in medium 162 containing $2.5 \mathrm{~g}$ of yeast extract per liter and $2.5 \mathrm{~g}$ of tryptone per liter and in minimal medium containing vitamin-free Casamino Acids $\left(0.2 \mathrm{~g} \mathrm{liter}^{-1}\right)$, and negative controls were grown in minimal medium without a carbon source. The following filter-sterilized carbon and energy sources were tested: amino acid mixture 1 as described by Hudson et al. (8); an amino acid mixture containing all 20 natural amino acids, each at a concentration of $40 \mathrm{mg} \mathrm{liter}{ }^{-1}$; single amino acids, each at a final concentration of $0.2 \mathrm{~g} \mathrm{liter}^{-1}$; and monosaccharides, disaccharides, organic acids, polyols, glycine-betaine, and $N$-acetylglucosamine, each at a final concentration of $0.2 \mathrm{~g} \mathrm{liter}^{-1}$. A filtersterilized vitamin and nucleotide supplement (23) was also added in initial tests in an attempt to improve growth in the minimal medium.

Polar lipid, lipoquinone, sphingolipid base, and fatty acid compositions. Cultures for polar lipid analysis were grown in 1-liter Erlenmeyer flasks containing $200 \mathrm{ml}$ of medium 162 supplemented with $1 \% \mathrm{NaCl}$ or without $\mathrm{NaCl}$ at $60^{\circ} \mathrm{C}$ in a reciprocal water bath shaker until the late exponential phase of growth. Harvesting of the cultures, extraction of the lipids, and two-dimensional thin-layer chromatography were performed as previously described (19).

Lipoquinones were extracted from freeze-dried cells and purified by thin-layer chromatography as described by Tindall (26). The lipoquinones were separated with a Gilson high-performance liquid chromatography apparatus by using a reverse-phase (RP18) column (Spherisorb S5 ODS2) with methanol-heptane $(10: 2, \mathrm{vol} / \mathrm{vol})$ as the mobile phase and were detected at $269 \mathrm{~nm}$. 
Sphingolipid bases were extracted and hydrolyzed from whole cells as described by Yabuuchi et al. (28) and Yano et al. (29). Ether extracts containing alkaline-hydrolyzed sphingolipid long-chain bases were developed on silica gel thin-layer chromatography plates (Kieselgel 60; Merck) with chloroform-methanol-water (65:25:4, by volume) and were visualized with ninhydrin $(0.2 \%$ in acetone).

Cultures for fatty acid analysis were grown on medium 162 plates in sealed plastic bags submerged in a water bath at $60^{\circ} \mathrm{C}$ for $24 \mathrm{~h}$. Fatty acid methyl esters (FAMEs) were obtained from fresh wet biomass by saponification, methylation, and extraction as described previously (12). The FAMEs were separated with a Hewlett-Packard model 5890 gas chromatograph equipped with a flame ionization detector fitted with a $5 \%$ phenylmethyl silicone capillary column $(0.2 \mathrm{~mm} \times$ $25 \mathrm{~m}$; Hewlett-Packard). The carrier gas was high-purity $\mathrm{H}_{2}$; the column head pressure was $60 \mathrm{kPa}$; the septum purge rate was $5 \mathrm{ml} \mathrm{min}^{-1}$; the column split ratio was 55:1; and the injection port temperature was $300^{\circ} \mathrm{C}$. The temperature of the oven was programmed to increase from 170 to $270^{\circ} \mathrm{C}$ at a rate of $5^{\circ} \mathrm{C}$ $\min ^{-1}$. Identification and quantification of the FAMEs, as well as a numerical analysis of the fatty acid profiles, were performed by using the standard MIS Library Generation software (Microbial ID, Inc., Newark, Del.).

Determination of $\mathbf{G}+\mathbf{C}$ content of DNA and DNA-DNA reassociation studies. The DNA was isolated as described by Cashion et al. (3). The $\mathrm{G}+\mathrm{C}$ content of the DNA was determined by high-performance liquid chromatography as described by Mesbah et al. (16).

DNA for DNA-DNA reassociation studies was isolated by chromatography on hydroxyapatite by the procedure of Cashion et al. (3). DNA-DNA hybridization was carried out as described by De Ley et al. (5), with the modifications described by $\mathrm{HuB}$ et al. (9), using a Gilford System model 2600 spectrophotometer equipped with a Gilford model 2527-R thermoprogrammer and plotter. Renaturation rates were computed with the TRANSFER.BAS program (10).

$16 S$ rDNA sequence determination and analysis. Genomic DNA extraction, PCR-mediated amplification of the $16 \mathrm{~S}$ ribosomal DNA (rDNA), and purification of PCR products were carried out as described previously (20). Purified PCR products were sequenced by using a Taq DyeDeoxy terminator cycle sequencing kit (Applied Biosystems, Foster City, Calif.) as directed in the manufacturer's protocol. Sequence reaction mixtures were electrophoresed with an Applied Biosystems model 373A DNA sequencer. The 16S rDNA sequences were aligned manually with the sequences of representatives of the cytophaga-flavobacterbacteroides lineage. Pairwise evolutionary distances were compared by using the correction of Jukes and Cantor (11). The least-squares distance method of De Soete (6) was used in the construction of a phylogenetic dendrogram from distance matrices.

Nucleotide sequence accession numbers. The 16S rDNA sequences of strains NR-27 ${ }^{\mathrm{T}}, \mathrm{SC}-1$, and AG3-1 have been deposited in the EMBL database under accession numbers Y08956, Y08957, and Y08958, respectively. The strain designations (where available) and accession numbers of the other sequences used in the analysis were as follows: Bacteroides fragilis ATCC $25285^{\mathrm{T}}$, M61006 Chryseobacterium gleum ATCC 35910 ${ }^{\mathrm{T}}$, M58772; Cytophaga diffluens ATCC $23140^{\mathrm{T}}$, M58765; Escherichia coli, J01695; Flavobacterium aquatile DSM $1132^{\mathrm{T}}$ M28236; Flexibacter flexilis ATCC $23079^{\mathrm{T}}$, M62794; Flexibacter roseolus ATCC $23088^{\mathrm{T}}$, M58787; Microscilla marina ATCC $23134^{\mathrm{T}}$, M58793; Rhodothermus marinus, X80994; Runella slithyformis ATCC $29530^{\mathrm{T}}$, M27799; Saprospira grandis ATCC $23119^{\mathrm{T}}$, M58795; Sphingobacterium heparinum ATCC $13125^{\mathrm{T}}$, M11657; and Thermonema lapsum, L11703.

\section{RESULTS AND DISCUSSION}

Isolation of strains and morphological and biochemical tests. The new Thermonema strains were isolated from three sites along the northern edge of the Bay of Naples. The hot spring at the Ristorante lo Scoglio is located on a beach a few meters from the edge of the Bay of Naples at Lucrino, Italy, and the hot spring at the Stufe di Nerone is located about 100 meters inland. These hot springs have water with a neutral $\mathrm{pH}$ value, temperatures of 62.5 and $66.2^{\circ} \mathrm{C}$, respectively, and $\mathrm{Na}^{+}$ levels of 11.36 and $5.98 \mathrm{~g} \mathrm{liter}^{-1}$, respectively. The spring at the Termi di Agnano is located about $3 \mathrm{~km}$ south of the other sites and about $2 \mathrm{~km}$ inland; the temperature at this site was $57^{\circ} \mathrm{C}$, the $\mathrm{pH}$ was 6.4 , and the $\mathrm{Na}^{+}$content was $1.98 \mathrm{~g} \mathrm{liter}^{-1}$.

All of the strains formed very thin, long, filamentous cells, produced bright yellow colonies on medium 162, and had an optimum growth temperature of about $60^{\circ} \mathrm{C}$, but did not grow at $70^{\circ} \mathrm{C}$ (Fig. 1). However, the new isolates could be easily distinguished from Thermonema lapsum DSM $5718^{\mathrm{T}}$ by their inability to grow in medium 162 without additional $\mathrm{NaCl}$ (Fig. 2). Strains SC-1 and NR-27 $7^{\mathrm{T}}$ exhibited optimum growth in medium 162 containing 1.0 to $3.0 \% \mathrm{NaCl}$, but did not grow in

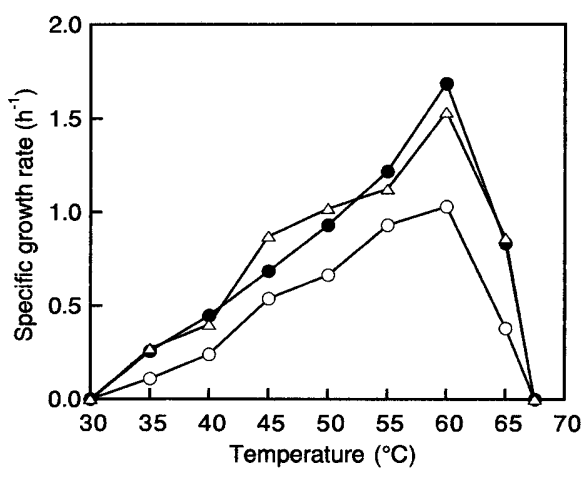

FIG. 1. Effect of temperature on the growth of Thermonema lapsum DSM $5718^{\mathrm{T}}(\mathrm{O})$, strain NR-27 $7^{\mathrm{T}}(\bullet)$, and strain SC-1 $(\Delta)$.

medium 162 containing $6.0 \% \mathrm{NaCl}$. On the other hand, Thermonema lapsum DSM $5718^{\mathrm{T}}$ exhibited optimum growth in medium 162 without added $\mathrm{NaCl}$, and growth decreased progressively as salt was added until no growth was observed in medium 162 containing $4.0 \% \mathrm{NaCl}$. The salt required by the Neapolitan strains was not replaced by $1.0 \% \mathrm{KCl}$ or $1.0 \%$ $\mathrm{MgCl}_{2}$.

All other phenotypic characteristics examined were identical in Thermonema lapsum DSM $5718^{\mathrm{T}}$ and strains NR-27 ${ }^{\mathrm{T}}$, SC-1, and AG3-1; these organisms degraded casein, gelatin, and hippurate, but did not hydrolyze starch, xylan, and cellulose. All of the strains grew on vitamin-free Casamino Acids, on complex amino acid mixture 1 of Hudson et al. (8), which does not contain cysteine, asparagine, glutamine, and tryptophan, on a mixture of the 20 natural amino acids, and on $0.25 \%$ yeast extract. Growth was not observed on single amino acids or on an amino acid mixture containing cysteine, asparagine, glutamine, and tryptophan. Growth did not occur on pentoses, hexoses, $N$-acetylglucosamine, disaccharides, glycine-betaine, polyols, and organic acids, including formate. The addition of a vitamin-nucleotide solution to the minimal medium did not improve growth.

The description of Thermonema lapsum stressed the inability of this species to grow on single amino acids (8), and this characteristic was also found in the new isolates. No simple explanation can be given for these results, although other bacteria (namely, members of the genus Legionella) also appear to require complex amino acid mixtures for growth (25). Moreover, growth was always poor in the minimal medium contain-

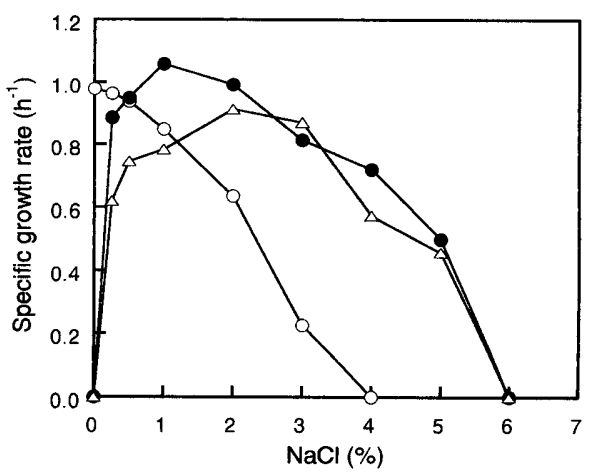

FIG. 2. Effect of $\mathrm{NaCl}$ concentration on the growth of Thermonema lapsum DSM $5718^{\mathrm{T}}(\mathrm{O})$, strain NR-27 $(\bullet)$, and strain SC-1 $(\Delta)$. 

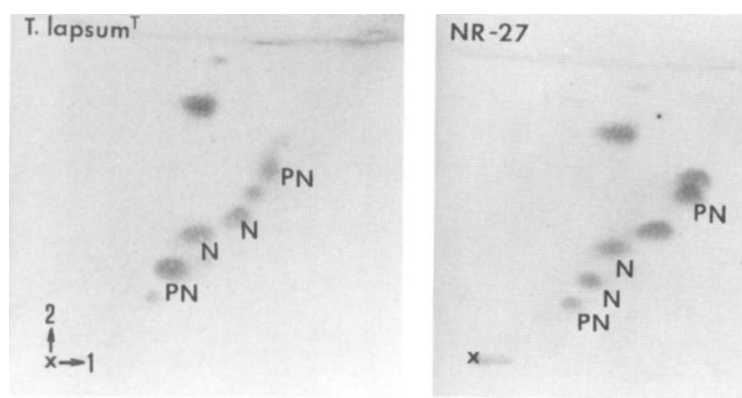

FIG. 3. Two-dimensional thin-layer chromatography of polar lipids of Ther monema lapsum DSM $5718^{\mathrm{T}}$ and strain NR-27 $7^{\mathrm{T}}$ stained by spraying with $5 \%$ molybdophosphoric acid, followed by heating at $160^{\circ} \mathrm{C}$. Abbreviations: $\mathrm{N}$, aminolipid; PN, aminophospholipid.

ing amino acid mixtures, and the strains lysed very rapidly at the onset of the stationary phase of growth, leading to a substantial decrease in the turbidity of the cultures in medium 162 and in the minimal medium. For this reason, growth was continuously monitored to avoid measuring growth during the latter part of the growth cycle when lysis had started.

Polar lipid, menaquinone, and fatty acid compositions. Menaquinone 7 was the major respiratory quinone, and two sphingosine bases were detected by thin-layer chromatography. The polar lipids of the strains examined were dominated by ninhydrin-positive lipids, two of which were aminophospholipids, and three lipids that did not react with $\alpha$-naphthol for carbohydrates or the Dittmer-Lester reagent for phosphoruscontaining lipids (Fig. 3).

The fatty acid composition of all of the strains was dominated by $15: 0$ iso ( 29.3 to $42.4 \%$ of the total fatty acids) and by $17: 0$ iso $3-\mathrm{OH}$ (17.4 to $22.4 \%$ of the total fatty acids); $15: 0$

TABLE 1. Mean fatty acid compositions of the strains studied after growth at $60^{\circ} \mathrm{C}$

\begin{tabular}{|c|c|c|c|}
\hline \multirow[b]{2}{*}{ Fatty acid ${ }^{a}$} & \multirow{2}{*}{$\begin{array}{c}\text { Equivalent } \\
\text { chain } \\
\text { length }\end{array}$} & \multicolumn{2}{|c|}{$\%$ in: } \\
\hline & & $\begin{array}{c}\text { Thermonema } \\
\text { lapsum }\end{array}$ & $\begin{array}{c}\text { Neapolitan } \\
\text { strains } \\
(n=6)\end{array}$ \\
\hline \multicolumn{4}{|l|}{ Nonhydroxy fatty acids } \\
\hline $14: 0$ iso & 13.617 & 1.0 & 1.5 \\
\hline $15: 0$ iso & 14.627 & 37.4 & 39.9 \\
\hline $15: 0$ anteiso & 14.713 & 8.4 & 8.6 \\
\hline $15: 0$ & 14.998 & 2.7 & 1.8 \\
\hline $16: 0$ iso & 15.625 & 1.0 & 1.5 \\
\hline $16: 0$ & 15.998 & 1.2 & 1.2 \\
\hline $17: 0$ iso & 16.629 & 1.1 & 1.2 \\
\hline $17: 1 \omega 6 \mathrm{c}$ & 16.861 & 1.3 & 0.8 \\
\hline Total & & 54.1 & 56.5 \\
\hline \multicolumn{4}{|l|}{ Hydroxy fatty acids } \\
\hline $15: 0$ iso $2 \mathrm{OH}$ & 15.843 & 7.4 & 5.4 \\
\hline $15: 0$ iso $3 \mathrm{OH}$ & 16.132 & 8.9 & 8.3 \\
\hline $15: 02 \mathrm{OH}$ & 16.222 & 1.2 & 0.6 \\
\hline $16: 0$ iso $3 \mathrm{OH}$ & 17.148 & 1.1 & 1.4 \\
\hline $16: 03 \mathrm{OH}$ & 17.519 & 1.5 & 1.3 \\
\hline $17: 0$ iso $2 \mathrm{OH}$ & 17.875 & 1.1 & 0.5 \\
\hline $17: 0$ iso $3 \mathrm{OH}$ & 18.162 & 17.4 & 18.7 \\
\hline 17:0 anteiso $3 \mathrm{OH}$ & 18.256 & 0.7 & 1.0 \\
\hline Total & & 39.3 & 37.2 \\
\hline Unknown & 16.580 & 2.0 & 2.1 \\
\hline
\end{tabular}

"Data for several fatty acids that were present at levels less than $1 \%$ in all strains are not included.

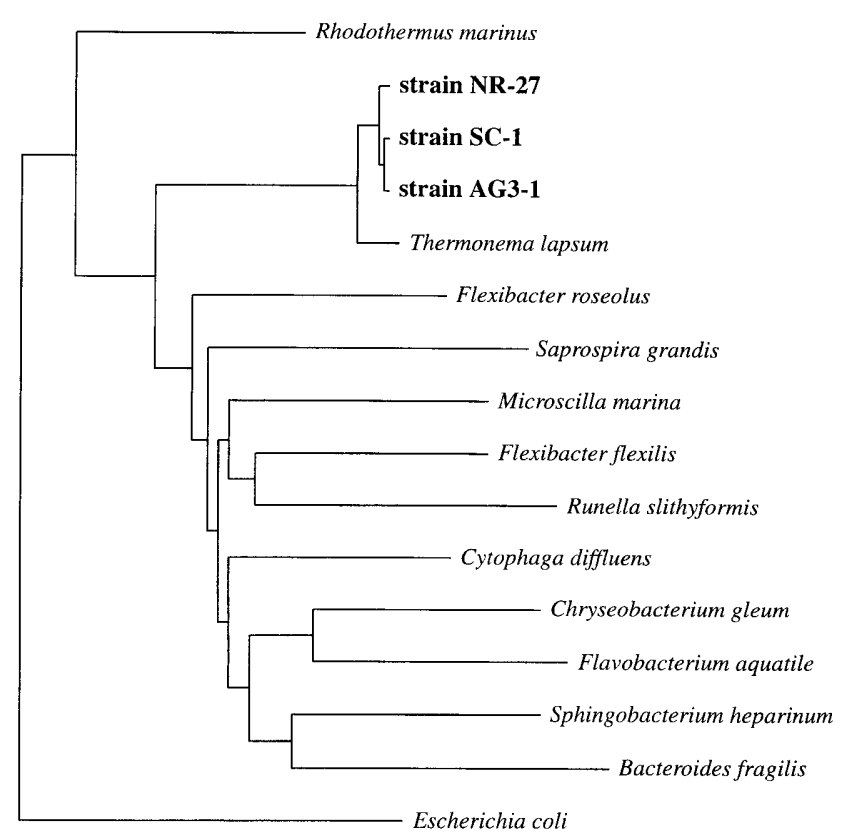

FIG. 4. Phylogenetic dendrogram based on $16 \mathrm{~S}$ rDNA sequence comparison, indicating the position of strains NR-27 ${ }^{\mathrm{T}}, \mathrm{SC}-1$, and $\mathrm{AG} 3-1$ within the radiation of representatives of the cytophaga-flavobacter-bacteroides phylum. Scale bar = 10 inferred nucleotide substitutions per 100 nucleotides.

anteiso, 15:0 iso 2-OH, and 15:0 iso $3-\mathrm{OH}$ were also found in moderate relative concentrations, but other fatty acids were minor or vestigial components. The total relative proportion of hydroxy fatty acids was very high, about $40 \%$ of the total fatty acids (Table 1).

The lipid composition allies these organisms with the species of the cytophaga-flavobacter-bacteroides phylum because of the presence of sphingolipids and the very large quantities of hydroxy fatty acids which are present in many species in this phylum (27). However, none of the chemotaxonomic parameters allowed the new isolates from Italy to be distinguished from Thermonema lapsum.

16S rRNA gene sequence analysis and DNA-DNA reassociation. Almost complete $16 \mathrm{~S}$ rDNA sequences $(>95 \%$ of the $E$. coli sequence) were determined for strains NR-27 ${ }^{\mathrm{T}}, \mathrm{SC}-1$, and AG3-1. The 16S rDNA sequences comprised 1,465 nucleotides for all three strains and covered the region between positions 37 and 1514 (E. coli numbering). Comparison of these sequences with sequences available from the public databases $(13,24)$ demonstrated that strains NR-27 ${ }^{\mathrm{T}}$, SC-1, and AG3-1 are related to the cytophaga-flavobacter-bacteroides phylum and, more precisely, to Thermonema lapsum (Fig. 4). The levels of $16 \mathrm{~S}$ rDNA sequence similarity between the new isolates and the other representatives of the cytophaga-flavobacterbacteroides phylum ranged from 79.0 to $97.5 \%$, based on a comparison of 1,275 unambiguous nucleotide positions. The highest levels of similarity were the levels of similarity to Thermonema lapsum (97.2 to $97.5 \%$ ). Pairwise comparison of the $16 \mathrm{~S}$ rDNA sequences (using all nucleotide positions between positions 37 and 1514 [E. coli numbering]) of Thermonema lapsum and strains $\mathrm{NR}-27^{\mathrm{T}}$, SC-1, and $\mathrm{AG} 3-1$ demonstrated that the levels of sequence similarity among the three new isolates were 99.2 to $99.7 \%$ and that the levels of similarity 
TABLE 2. DNA-DNA reassociation results

\begin{tabular}{lccc}
\hline \multirow{2}{*}{ Organism } & \multicolumn{3}{c}{ \% Reassociation with: $^{2}$} \\
\cline { 2 - 4 } & Strain NR-27 & Strain SC-1 & Strain AG3-1 \\
\hline Strain NR-27 & & & \\
Strain SC-1 & 96.0 & & \\
Strain AG3-1 & 91.6 & 103.0 & \multirow{2}{*}{ Thermonema lapsum } \\
\hline
\end{tabular}

between Thermonema lapsum and the new isolates were 96.5 to $96.8 \%$.

DNA-DNA reassociation studies were used to confirm the species status of the three new isolates in relation to Thermonema lapsum. The results of DNA-DNA reassociation studies are given in Table 2. These results confirm the high degree of relatedness among the three new isolates found by $16 \mathrm{~S}$ rDNA sequence comparison. The values greater than $91 \%$ indicate that all three strains belong to a single species. The species status of these three isolates was demonstrated by the reassociation values obtained in comparisons with Thermonema lapsum (36.9 to $40.6 \%)$.

Str ins of Thermonema lapsum have been isolated only from terre rial, nonsaline hot springs in the Rotorua area of New Zealand. Our results show that Thermonema lapsum is not halophilic but is more halotolerant tha most Thermus spp. strains isolated from nonmarine hot springs $(7,14,15)$. On the other hand, the strains of Thermus thermophilus that originated from terrestrial or marine geothermal areas are slightly more halotolerant than Thermonema lapsum. The other aerobic thermophilic bacterium isolated from shallow marine hot springs, Rhodothermus marinus, is slightly halophilic, requiring about $0.25 \% \mathrm{NaCl}$, but does not grow in media containing more than about $6.0 \% \mathrm{NaCl}$ (17). The new Thermonema sp. strains isolated from Italy are also slightly halophilic, but have a very low $\mathrm{Na}^{+}$requirement. The strains from Agnano, in contrast to the isolates from Ristorante lo Scoglio and Stufe di Nerone, originated from hot springs having low levels of salinity, indicating that these organisms can also colonize environments where the $\mathrm{Na}^{+}$concentration is low.

The $16 \mathrm{~S}$ rDNA sequence analysis clearly demonstrated that strains NR-27 ${ }^{\mathrm{T}}, \mathrm{SC}-1$, and AG3-1 are members of the genus Thermonema. The high degrees of $16 \mathrm{~S}$ rDNA sequence similarity among these three strains shows that they belong to one species, which is distinct from Thermonema lapsum. This was confirmed by DNA-DNA reassociation studies. On the basis of these data and the halophilic nature of the strains, we propose a new species for strains NR-27 ${ }^{\mathrm{T}}$, SC-1, and AG3-1.

Description of Thermonema rossianum sp. nov. Nobre, Rainey, and da Costa. Thermonema rossianum (ros. si. a' num. M. L. adj. rossianum, pertaining to Rossi, in honor of Mosé Rossi, noted Neapolitan biochemist). Thermonema rossianum strains form long filaments of variable length, which are about $0.7 \mu \mathrm{m}$ wide. Gram stain negative. The cells are nonmotile, and spores are not formed. Colonies on medium 162 are yellow pigmented and $2 \mathrm{~mm}$ in diameter after $48 \mathrm{~h}$ of growth. The optimum growth temperature for strain NR-27 is about $60^{\circ} \mathrm{C}$; growth does not occur at 30 and $70^{\circ} \mathrm{C}$ in medium 162. The optimum $\mathrm{pH}$ is between 7.0 and 7.5; growth does not occur at $\mathrm{pH} 5.0$ or 10.0 . The optimum $\mathrm{NaCl}$ concentration for growth is between 1.0 and $3.0 \%$; growth does not occur in medium 162 without added $\mathrm{NaCl}$ or in medium containing an $\mathrm{NaCl}$ concentration greater than $6.0 \%$. The major fatty acids are 15:0 iso and 17:0 iso $3-\mathrm{OH}$. The major respiratory quinone is menaquinone 7 ; sphingolipids are present. All strains are oxidase pos- itive and catalase positive. Nitrate is not reduced to nitrite. Casein, elastin, and gelatin are degraded; starch, xylan, and cellulose are not degraded. The strains utilize Casamino Acids and complex amino acid mixtures for growth. The strains of this species do not grow on single amino acids, sugars, organic acids, and polyols.

The DNA of strain NR $-27^{\mathrm{T}}$ has a $\mathrm{G}+\mathrm{C}$ content of 50.9 mol\%. This bacterium was isolated from a saline hot spring close to the Bay of Naples. Strain NR-27 ${ }^{\mathrm{T}}$ has been deposited in the Deutsche Sammlung von Mikroorganismen und Zellkulturen, Braunschweig, Germany, as strain DSM $10300^{\mathrm{T}}$. Strains SC-1 (= DSM 10298) and AG3-1 (= DSM 10299) are reference strains of this species.

\section{ACKNOWLEDGMENTS}

This work was supported by European Community Biotech Program (Biotechnology of Extremophiles) contract BIO2-CT93-0274, by European Community MAST program contract MAS3-CT95-0034. by Junta Nacional de Investigação Científica e Tecnológica grant JNICT STRA/BIO/367/92), and by Praxis XXI Program grant Praxis 2/2.1/ $\mathrm{BIO} / 20 / 94$ (Portugal).

We are indebted to Brian Tindall (Deutsche Sammlung von Mikroorganismen und Zellkulturen, Braunschweig, Germany) for many helpful suggestions.

\section{REFERENCES}

1. Alfredsson, G. A., J. K. Kristjansson, S. Hjorleifsdottir, and K. O. Stetter. 1988. Rhodothermus marinus, gen. nov., sp. nov., a thermophilic, halophilic bacterium from submarine hot springs in Iceland. J. Gen. Microbiol. 134: 299-306.

2. Blöchl, E., S. Burggraf, G. Fiala, G. Lauerer, G. Huber, R. Huber, R. Rachel, A. Segerer, K. O. Stetter, and P. Völkl. 1995. Isolation, taxonomy and phylogeny of hyperthermophilic microorganisms. World J. Microbiol. Biotechnol. 11:9-16.

3. Cashion, P., M. A. Holder-Franklin, J. McCully, and M. Franklin. 1977. A rapid method for the base ratio determination of bacterial DNA. Anal. Biochem. 81:461-466.

4. Degryse, E., N. Glansdorff, and A. Piérard. 1978. A comparative analysis of extreme thermophilic bacteria belonging to the genus Thermus. Arch. Microbiol. 117:189-196.

5. De Ley, J., H. Cattoir, and A. Reynaerts. 1970. The quantitative measurement of DNA hybridization from renaturation rates. Eur. J. Bichem. 12:133 142 .

6. De Soete, G. 1983. A least squares algorithm for fitting additive trees to proximity data. Psychometrika 48:621-626.

7. Hudson, J. A., H. W. Morgan, and R. M. Daniel. 1989. Numerical classification of Thermus isolates from globally distributed hot springs. Syst. Appl. Microbiol. 11:250-256.

8. Hudson, J. A., K. M. Schofield, H. W. Morgan, and R. M. Daniel. 1989. Thermonema lapsum gen. nov., sp. nov., a thermophilic gliding bacterium. Int. J. Syst. Bacteriol. 39:485-487.

9. Huß, V. A. R., H. Festl, and K.-H. Schleifer. 1983. Studies on the spectrophotometric determination of DNA hybridization from renaturation rates. Syst. Appl. Microbiol. 4:184-192.

10. Jahnke, K.-D. 1992. BASIC computer program for evaluation of spectroscopic DNA renaturation data from Gilford System 2600 spectrophotometer on a PC/XT/AT type personal computer. J. Microbiol. Methods 15:61-73.

11. Jukes, T. H., and C. R. Cantor. 1969. Evolution of protein molecules, p. 21-132. In H. N. Munro (ed.), Mammalian protein metabolism. Academic Press, New York, N.Y.

12. Kuykendall, L. D., M. A. Roy, J. J. O'Neill, and T. E. Devine. 1988. Fatty acids, antibiotic resistance, and deoxyribonucleic acid homology groups of Bradyrhizobium japonicum. Int. J. Syst. Bacteriol. 38:358-361.

13. Maidak, B. L., N. Larsen, M. J. McCaughey, R. Overbeck, G. J. Olsen, K. Fogel, J. Blandy, and C. R. Woese. 1994. The Ribosomal Database Project. Nucleic Acids Res. 22:3483-3487.

14. Manaia, C. M., and M. S. da Costa. 1991. Characterization of halotolerant Thermus isolates from shallow marine hot springs on S. Miguel, Azores. J. Gen. Microbiol. 137:2643-2648.

15. Manaia, C. M., B. Hoste, M. C. Gutierrez, M. Gills, A. Ventosa, K. Kersters, and M. S. da Costa. 1994. Halotolerant Thermus strains from marine and terrestrial hot springs belong to Thermus thermophilus (ex Oshima and Imahori, 1974) nom. rev. emend. Syst. Appl. Microbiol. 17:526-532.

16. Mesbah, M., U. Premachandran, and W. B. Whitman. 1989. Precise measurement of the $\mathrm{G}+\mathrm{C}$ content of deoxyribonucleic acid by high-performance liquid chromatography. Int. J. Syst. Bacteriol. 39:159-167. 
17. Nunes, O. C., M. M. Donato, and M. S. da Costa. 1992. Isolation and characterization of Rhodothermus strains from S. Miguel, Azores. Syst. Appl. Microbiol. 15:92-97.

18. Patel, B. K. C., D. S. Saul, R. A. Reeves, L. C. Williams, J.-E. Cavanagh, P. D Nichols, and P. L. Bergquist. 1994. Phylogeny and lipid composition of Thermonema lapsum, a thermophilic gliding bacterium. FEMS Microbiol. Lett. 115:313-318.

19. Prado, A., M. S. da Costa, and V. M. C. Madeira. 1988. Effect of growth temperature on the lipid composition of two strains of Thermus sp. J. Gen. Microbiol. 134:1653-1660.

20. Rainey, F. A., M. Dorsch, H. W. Morgan, and E. Stackebrandt. 1992. 16S rDNA analysis of Spirochaeta thermophila: its phylogenetic position and implications for the systematics of the order Spirochaetales. Syst. Appl. Microbiol. 15:197-202.

21. Santos, M. A., R. A. D. Williams, and M. S. da Costa. 1989. Numerical taxonomy of Thermus isolates from hot springs in Portugal. Syst. Appl. Microbiol. 12:310-315.

22. Schofield, K. M., J. A. Hudson, H. W. Morgan, and R. M. Daniel. 1987. A thermophilic gliding bacterium from New Zealand hot springs. FEMS Microbiol. Lett. 40:169-172.
23. Sharp, R. J., and R. A. D. Williams. 1988. Properties of Thermus ruber strains isolated from Icelandic hot springs and DNA-DNA homology of Thermus ruber and Thermus aquaticus. Appl. Environ. Microbiol. 54:2049-2053.

24. Strunk, O., and W. Ludwig. 1995. ARB - a software environment for sequence data (retrievable from arb@mikro.biologie.tu-muenchen.de). Lehrstuhl für Mikrobiologie, Technical University of Munich, Munich, Germany.

25. Tesh, M. T., and R. D. Miller. 1981. Amino acid requirements for Legionella pneumophila growth. J. Clin. Microbiol. 13:865-869.

26. Tindall, B. J. 1989 . Fully saturated menaquinones in the archaebacterium Pyrobaculum islandicum. FEMS Microbiol. Lett. 60:251-254.

27. Wilkinson, S. G. 1988. Gram-negative bacteria, p. 299-488. In C. Ratledge and S. G. Wilkinson (ed.), Microbial lipids, vol. 1. Academic Press, London, United Kingdom.

28. Yabuuchi, E., E. Tanimura, A. Ohyama, I. Yano, and A. Yamamoto. 1979. Flavobacterium devorans ATCC 10829: a strain of Pseudomonas paucimobilis. J. Gen. Microbiol. 25:95-107.

29. Yano, I., I. Tomiyasu, and E. Yabuuchi. 1982. Long chain base composition of strains of three species of Sphingobacterium gen. nov. FEMS Microbiol. Lett. 15:303-307. 